\title{
Variation in the level of aggression, chemical and genetic distance among three supercolonies of the Argentine ant in Europe
}

\author{
O. BLIGHT,${ }^{* 1}$ L. BERVILLE,${ }^{* 1}$ V. VOGEL,$+^{1}$ A. HEFETZ, $\ddagger$ M. RENUCCI $§$ J. ORGEAS,$*$ \\ E. PROVOST $\S$ and L. KELLER† \\ *Aix-Marseille Université (Paul Cézanne), Institut Méditerranéen de Biodiversité et d'Ecologie marine et continentale (UMR \\ CNRS/IRD), Université Paul Cézanne, Europôle Méditerranéen de l'Arbois BP 80, 13545 Aix-en-Provence Cedex 4, France, \\ tDepartment of Ecology and Evolution, University of Lausanne, Biophore, CH-1015 Lausanne, Switzerland, $\ddagger$ Department of \\ Zoology, George S. Wise Faculty of Life Sciences, Tel Aviv University, Ramat Aviv 69978, Israel, §CNRS, UMR 6116, \\ Aix-Marseille Université (Paul Cézanne), Institut Méditerranéen de Biodiversité et d'Ecologie marine et continentale (UMR \\ CNRS/IRD), Université Paul Cézanne, Europôle Méditerranéen de l'Arbois BP 80, 13545 Aix-en-Provence Cedex 4, France
}

\begin{abstract}
In their invasive ranges, Argentine ant populations often form one geographically vast supercolony, genetically and chemically uniform within which there is no intraspecific aggression. Here we present regional patterns of intraspecific aggression, cuticular hydrocarbons (CHCs) and population genetics of 18 nesting sites across Corsica and the French mainland. Aggression tests confirm the presence of a third European supercolony, the Corsican supercolony, which exhibits moderate to high levels of aggression, depending on nesting sites, with the Main supercolony, and invariably high levels of aggression with the Catalonian supercolony. The chemical analyses corroborated the behavioural data, with workers of the Corsican supercolony showing moderate differences in CHCs compared to workers of the European Main supercolony and strong differences compared to workers of the Catalonian supercolony. Interestingly, there were also clear genetic differences between workers of the Catalonian supercolony and the two other supercolonies at both nuclear and mitochondrial markers, but only very weak genetic differentiation between nesting sites of the Corsican and Main supercolonies $\left(F_{\mathrm{ST}}=0.06\right)$. A detailed comparison of the genetic composition of supercolonies also revealed that, if one of the last two supercolonies derived from the other, it is the Main supercolony that derived from the Corsican supercolony rather than the reverse. Overall, these findings highlight the importance of conducting more qualitative and quantitative analyses of the level of aggression between supercolonies, which has to be correlated with genetic and chemical data.
\end{abstract}

Keywords: aggression, cuticular hydrocarbons, Linepithema humile, population genetics, supercolonies

Received 8 March 2011; revision received 15 March 2012; accepted 24 March 2012

\section{Introduction}

The ability to recognize self from non-self is a central characteristic of social insects and is crucial for maintaining social structure (Hölldobler \& Wilson 1990; Smith \&

Correspondence: O. Blight, Fax: + (33) 04912886 68;

E-mail: olivier.blight@gmail.com

${ }^{1}$ These authors contributed equally to this study.
Breed 1995). Social insects have a highly developed recognition system that enables them, on the one hand, to behave altruistically towards nestmates and, on the other hand, to act aggressively towards non-nestmates, thus protecting the colony from colony resource exploitation by conspecific intruders. Nestmate recognition is based on a distinct colony odour (label), which in social insects, including ants, bees, wasps and termites, is composed of 
cuticular hydrocarbons (CHCs) (Lahav et al. 1999; see also Hefetz 2007 and Provost et al. 2008). A mismatch between the CHCs of intruder and resident workers generally leads to aggression.

Most ant species are multicolonial, with well-developed nestmate discrimination whereby workers aggressively defend territories against either conspecifics or heterospecific colonies (Hölldobler \& Wilson 1990). However, in some species, there is greatly reduced aggression between colonies. An extreme case of such reduced levels of aggression occurs in unicolonial species that are characterized by the presence of supercolonies consisting of large networks of nests exhibiting no aggression within supercolonies but high aggression between supercolonies (Tsutsui et al. 2000; Giraud et al. 2002; Le Breton et al. 2004; Errard et al. 2005; Pedersen et al. 2006; Thomas et al. 2010). A peculiarity of supercolonies is that they range over spatial scales that are so large that direct interactions among workers of all nests are impossible (Pedersen et al. 2006). Unicolonial species are ecologically among the most successful organisms, with very high invasive potential (Holway et al. 2002).

The Argentine ant (Linepithema humile) provides a good example of the invasion success of unicolonial species. This invader has successfully spread across many zones of the globe with Mediterranean and subtropical climates, through the intensification of human activities over the last century (Suarez et al. 2001). Its unicolonial structure affords it major ecological advantages in terms of colonization ability (Holway 1999; Tsutsui et al. 2000; Giraud et al. 2002), resource exploitation (Holway \& Case 2001) and interspecific competition (Human \& Gordon 1996; Holway 1999), allowing Argentine ant populations to reach high densities of workers (Holway et al. 1998, 2002). In their introduced range, Argentine ant populations often form one geographically vast supercolony, genetically and chemically uniform within which there is no intraspecific aggression (Tsutsui et al. 2000; Giraud et al. 2002; Sunamura et al. 2009a). Studies on the Argentine ant in its introduced range have described a large number of supercolonies worldwide (Tsutsui et al. 2000; Giraud et al. 2002; Suhr et al. 2009; Sunamura et al. 2009a). Interestingly, several supercolonies extending over hundreds of kilometres in the USA, Europe, Australia and Hawaii have been found to be chemically and genetically similar (Brandt et al. 2009; Vogel et al. 2010) and exhibit no mutual aggression (Sunamura et al. 2009b; van Wilgenburg et al. 2010), suggesting that they belong to a single global supercolony. Frequent movements and introductions of Argentine ant propagules in distant parts of the global supercolony may facilitate its persistence by avoiding genetic and chemical changes resulting from isolation by distance (van Wilgenburg et al. 2010).
While it was thought that there are two supercolonies in Europe (Giraud et al. 2002), a recent study identified a third supercolony, the Corsican supercolony, which elicited moderate levels of aggression toward the Main European supercolony and was chemically closer to the Main European supercolony than to the Catalonian supercolony (Blight et al. 2010). On the basis of these results, the authors suggested that the Corsican supercolony may represent a third European supercolony originating either from the Main European supercolony or from an independent introduction event. Unfortunately, no information is available on the genetic composition of the Corsican supercolony. Moreover, a misidentification was made on the identity of the Main and the Corsican supercolonies with the control nesting site previously used for the Main supercolony actually belonging to the Corsican supercolony (see results of this study).

To get a better understanding of the process by which invasive ant supercolonies are segregated and their evolutionary trajectories, we first conducted additional behavioural tests to obtain quantitative data on the level of aggression between putative nesting sites from the Corsican and Main supercolonies. In addition to the six previously studied nesting sites (Blight et al. 2010), we investigated 12 additional nesting sites, seven from Corsica and five from continental France. Moreover, to determine whether the Corsican supercolony may possibly originate from the Main or Catalonian supercolonies, we conducted a genetic analysis where we compared the genotypes of workers from each of the three supercolonies at 12 microsatellites loci and one fragment of the mitochondrial cytochrome $b$ gene (Vogel et al. 2010). Finally, we complemented these studies by analysing the CHCs of workers collected from all the studied sites. This allowed us to compare the behavioural, genetic and chemical differentiation of individuals from each of the three supercolonies.

\section{Materials and methods}

\section{Study context and field collection}

We collected nests of Linepithema humile from 18 sites in southern Europe. Sixteen colony fragments were collected in France: 10 along the Corsican coast (Ajaccio-AJA, Biguglia-BIG, Calvi-CAL, Campomoro-CAM, Cannella-CAN, Liamone-LIA, Olmeto-OL, PortoVecchio-PVE, Santa Giulia-SGI, and Tizzano-TIZ) and six on the coast of continental France (Anthéor-ANT, Ceyreste-CEY, Danio-DAN, Les Embiez-EMB, Fréjus-FRE and Théoule-THE). The remaining two nesting sites were collected in Spain, one in Caldès d'Estrac (CDE) and the other in Sant Feliù de Guixols (SFG). 
Unfortunately, only one of these nests (CDE) was found to actually belong to the Catalonian supercolony (see results), hence requiring to use a single nesting site for all the tests including the Catalonian supercolony. However, the inclusion of a single nesting site for the Catalonian supercolony has only limited consequences for this study whose primary aim is to compare the Main and Corsican supercolonies. In that respect, it is important to note that the previous studies have shown that aggression is invariably high between nests of the Catalonian supercolony and nests of both the Corsican and Main supercolonies (Giraud et al. 2002; Jaquiéry et al. 2005; Blight et al. 2010). The level of aggression observed in the present study was the same as that observed in those studies. Moreover, the hydrocarbon profiles of the workers from CDE were typical of those of nests of the Catalonian supercolony (see Blight et al. 2010). Finally, the genetic data on individuals of the nesting site CDE are also completely congruent with those obtained with other nests of the Catalonian supercolony (Giraud et al. 2002; Vogel et al. 2010). In particular, the alleles of the microsatellites loci Lhum-18 and Lhum-28 and the haplotype H9 characteristic of the Catalonian supercolony (Jaquiéry et al. 2005 and Vogel et al. 2010) were all detected in the nesting site of CDE (see result section). Thus, although we acknowledge a problem of pseudoreplication in the statistical analyses, we believe that the main results of this study are not influenced by the inclusion of a single nest of the Catalonian supercolony.

Colony fragments were collected in October 2008 with a minimum of 10000 workers and 20 queens. These were kept in a plastic nest container $(360 \times 240 \times 110 \mathrm{~mm})$ filled with their original substrate. In addition to the arthropods caught with the original substrate that served as a protein source, the colonies were supplied with honey and water ad libitum. Colony fragments were maintained in the laboratory at $23 \pm 2{ }^{\circ} \mathrm{C}$ with soil moisture. From each of the 18 nesting sites, we also froze some workers immediately upon collection for chemical analyses and stored others in alcohol for the genetic analyses.

\section{Behavioural assays}

We assessed the level of worker-worker aggression between all nesting sites using combinations of pairwise encounters consisting of confrontations between two groups of 100 workers that were competing for food and nesting space (Blight et al. 2010). Before each assay, workers from each of the two nesting sites were placed in closed artificial nests $(60 \times 45 \times 50 \mathrm{~mm})$ with their own nest material and moist cotton for $1 \mathrm{~h}$, for acclimatization and construction of small galleries. The nests were connected via plastic tubes to a common foraging arena $(60 \times 90 \times 50 \mathrm{~mm})$ provided with honey in the centre; following acclimatization, the workers were allowed access to the foraging arena. We monitored behavioural interactions among workers for $20 \mathrm{~min}$, using the following classification of interactions: (i) touch (contacts including prolonged antennation); (ii) avoidance (contacts followed by at least one ant running away); (iii) aggression ( $<2 \mathrm{~s}$, lunging, biting); (iv) asymmetrical intense aggression $(>2 s$, at least one aggressor and one non-aggressive individual, lunging, biting, pulling legs or antennae) and (v) symmetrical intense fighting (all individuals are aggressors; gaster flexion; death a few seconds after the beginning of fights). Scores 3, 4 and 5 were considered as aggressive interactions. The highest score observed during the $20 \mathrm{~min}$ for each assay was recorded. To minimize the effect of pseudoreplication, aggression scores were averaged across replicates and used as the aggression index of the nest pair. Twenty-four hours after the beginning of the experiment, the trial was stopped to count dead and living workers. Three replicates were conducted for each of the 153 pairs of nesting sites and 16 within-nest confrontations (control). Due to limiting number of individuals, we were not able to conduct three replicates for all confrontations involving the CAL and BIG nesting sites, as well the within-nest confrontations in these nesting sites. Individuals were used only once per behavioural test. The supercolony affiliation of each nesting site was determined according to the above bioassay. Two nesting sites exhibiting aggression (score above 2) were classified as belonging to different supercolonies, whereas those with indices of 1 or 2 were classified as belonging to the same supercolony. Differences in levels of aggression and mortality rates were compared with the non-parametric Mann-Whitney $U$ test.

\section{Cuticular hydrocarbon analyses}

We first identified by gas chromatography/mass spectrometry (GC/MS) the cuticular compounds of a pool of 30 workers from one nesting site of each of the three European supercolonies (CDE for the Catalonian supercolony, CEY for the Main European supercolony and FRE for the Corsican supercolony). For extractions, we immersed 30 workers of each nesting site for $1 \mathrm{~h}$ in $100 \mu \mathrm{L}$ of hexane. After extract concentration, $2 \mathrm{~mL}$ of each sample were injected into an Agilent 6890N GC equipped with Chrompack CPSil5WCOT apolar capillary column (fused silica, $25 \mathrm{~m} \times 0.25 \mathrm{~mm}$; thickness of stationary phase, $0.12 \mu \mathrm{m})$. The injector was in splitless mode with helium carrying gas flow at $1 \mathrm{~mL} / \mathrm{min}$. Initial oven temperature was held at $70{ }^{\circ} \mathrm{C}$ for $1 \mathrm{~min}$ and then increased at a rate of $30^{\circ} \mathrm{C} / \mathrm{min}$ to $180{ }^{\circ} \mathrm{C}$, 
followed by $5{ }^{\circ} \mathrm{C} / \mathrm{min}$ to $320^{\circ} \mathrm{C}$, and a final hold of $15 \mathrm{~min}$. The GC was coupled with a 5375 Agilent Technologies Mass Spectrometer, using $70 \mathrm{eV}$ electron impact ionization. Compounds were identified on the basis of their mass spectra in comparison with standard compounds, when available, and published spectra.

Second, we quantified CHCs of 10 individual workers from each of the 18 nesting sites by individually immersing them in $10 \mu \mathrm{L}$ of hexane for $15 \mathrm{~min}$. The samples were analysed using capillary gas chromatography (Varian 3900 Gas chromatograph), equipped with a flame ionization detector and a Chrompack CPSil5WCOT apolar capillary column (fused silica, $25 \mathrm{~m} \times 0.25 \mathrm{~mm}$; thickness of stationary phase, $0.12 \mu \mathrm{m})$. Oven temperature was programmed from 100 to $220^{\circ} \mathrm{C}$ at the rate of $10^{\circ} \mathrm{C} / \mathrm{min}$, then from 220 to $320^{\circ} \mathrm{C}$ at the rate of $3{ }^{\circ} \mathrm{C} / \mathrm{min}$, with a final hold of $10 \mathrm{~min}$. Comparison of cuticular profiles was based on the proportions of 51 major CHCs displayed on a chromatogram by using Star 5.5 (Varian) software. Integrated values were adjusted by applying the correction coefficient $\mathrm{K}=0.0038 \mathrm{X}^{2}-0.1738 \mathrm{X}+2.9683$, where $X$ is the number of carbon atoms, which corrects variations in detector sensitivity as a function of carbon chain length. This coefficient was determined after injection of the same quantity of $14 \mathrm{n}$-alkanes with chain lengths of $18,20,22,24,28,32,34,36,38,40,42,44,46$ and 48 carbon atoms, respectively.

Between nesting-site variability in profile composition was assessed using multivariate principal component analysis (PCA; Statistica v.6, Statsoft 2001) based on the relative proportion of the $\mathrm{CHCs}$ identified. In total, we identified 130 peaks but only used the 51 peaks that accounted for at least $0.5 \%$ of the overall peak area of the whole profile in one of the nesting sites. As the resulting data matrix contained many zeros (CHCs present in a profile but absent from another), standard multivariate procedures were not applicable. We thus attributed a very small value $(0.001 \%)$ to eliminate the zeros. We also conducted a separate $K$-means cluster analysis to group together data points showing similar cuticular hydrocarbon profiles (Hartigan \& Wong 1979). The number of groups to be obtained is unknown a priori, and the choice is somewhat arbitrary. To select an optimum number, we used the ratio of inter- to intragroup variance of an increasing number of groups, considering a stopping rule when the gain was $<0.10$.

\section{Genetic analyses}

DNA was extracted from 10 workers per nesting site (total 180) using the Puregene DNA Isolation Kit (Gentra Systems) and analysed at 12 microsatellite loci: Lhum-3, Lhum-11, Lhum-13, Lhum-19, Lhum-28, Lhum-33,
Lhum-35, Lhum-39, Lhum-52, Lhum-62, Lihu-S3 and LihuT1 (Krieger \& Keller 1999; Tsutsui et al. 2000). PCR products were separated on polyacrylamide gels and run on an ABI $377 \mathrm{XL}$ automated sequencer (Applied Biosystems) with subsequent scoring of alleles using GENEMAPPER 4.0 (Applied Biosystems). One fragment of the mitochondrial DNA was also amplified for one worker per nesting site (524 bp of the cytochrome $b$ gene, Pedersen et al. 2006). After PCR products were checked on a $1.5 \%$ agarose gel, they were purified using the QIAquick purification kit (Qiagen, Valencia, CA, USA) and directly double-stranded sequenced by the automated sequencer using the BigDye terminator ready-reaction kit. Sequence data were edited and compiled using LASERGENE 7.1.0 (Dnastar Inc., USA).

To confirm the assignment of nesting sites to the Main, the Corsican and the Catalonian supercolonies, we used a Bayesian clustering method. Bayesian clustering methods were used to determine, without a priori assumptions, the number of genetic groups in a data set and subsequently to assign individuals or groups of individuals to these genetic groups. This approach has been recognized as efficient for the identification of supercolonies, because the clustering of nests is highly congruent with aggression tests (Jaquiéry et al. 2005; Pedersen et al. 2006; Vogel et al. 2009). We used the clustering method implemented in structure 2.1 (Pritchard et al. 2000). This method infers the number of different clusters $(K)$ that best suit a data set and assigns individuals to the inferred clusters. All simulations performed in STRUCTURE featured 500000 runs following a burn-in period consisting of 100000 runs. Ten separate runs were performed for each value of $K$ tested (between 1 and 15). We ensured accurate estimates of the simulation values by checking that model parameters equilibrated before the end of the burn-in phase and that posterior probabilities were consistent across all ten runs. Then, we determined the appropriate value of $K$ for each data set using the $\Delta K$ method of Evanno et al. (2005). For the analyses, each nesting site was considered as a group, and the maximum number of genetically divergent groups $(K)$ was set at 18 , the number of nesting sites included in the data set. Each analysis was repeated 10 times to ensure consistency of results between different runs. To prevent the high level of genetic differentiation owing to the presence of Catalonian samples from obscuring the structure of the two supercolonies of interest here, we performed all the above analyses both with and without the Catalonian nesting site (CDE).

To determine the genetic structure of the 18 nesting sites forming the three supercolonies, we assessed genetic differentiation with three different approaches. First, pairwise $F_{\mathrm{ST}}$ we computed with FSTAT 2.9.3.2 
(Goudet 1995) between all pairs of supercolonies and nesting sites. For these pairwise comparisons, significance levels for multiple tests were adjusted according to the Bonferroni corrections. Second, to compare the level of structure between and within the three supercolonies, a hierarchical analysis was performed with HIERFSTAT (Goudet 2005). The different levels considered were the individuals (Ind), within nesting sites (Nest) and nesting sites within the supercolonies (Sc). Significance of $F_{\text {Nest/Sc }}$ was tested in HIERFSTAT (de Meeus \& Goudet 2007) with 10000 permutations of individuals between nests within supercolonies and $F_{\mathrm{Sc} / \text { Pop }}$ with 10000 permutations of nests between supercolonies. This analysis was performed with and without the nesting site belonging to the Catalonian supercolony (CDE). Finally, to infer the relationship between the nesting sites, we performed a principal component analyses (PCA) on the microsatellite data using the program PCAGEN 1.2 (Goudet 2000). The per cent inertia of each principal component axis and its respective $P$ value were estimated by performing 10000 randomizations of multilocus genotypes. This analysis was also performed with and without the nesting site belonging to the Catalonian supercolony (CDE).

To investigate the relationship between the different nesting sites sampled and the worldwide supercolonies described in Vogel et al. (2010), we performed a principal component analyses (PCA) on the microsatellite data using the program PCAGEN 1.2 (Goudet 2000) by using all the nesting sites of the present study and those of Vogel et al. (2010). To obtain more detailed information on the relationship between the Main and Corsican supercolonies, we conducted the same analysis by considering only supercolonies harbouring the $\mathrm{H} 1$ haplotype and excluding the South Africa population because it was clearly differentiated from all other supercolonies with the H1 haplotype (see Fig. 4A). The same set of 12 microsatellites was used for all analyses and all the analyses performed by the same person (V.V.) in the same laboratory (Lausanne). The per cent inertia of each principal component axis and its respective $P$ value were estimated by performing 10000 randomizations of multilocus genotypes.

To test the hypothesis that the Corsican supercolony derived from the Main supercolony, we measured the allelic richness for each nesting site and each supercolony, correcting the observed number of alleles to the estimated value for the minimum common sample size using rarefaction statistics (Petit et al. 1998). Statistical significance of differences in allelic richness (corrected number of alleles) per locus between the Main and Corsican nesting sites were assessed in two-sided permutation tests applying 15000 randomizations. We also estimated the allelic nestedness by estimating, for each pair of nesting sites, the percentage of alleles found in one nesting site that were also present in the other nesting site and vice versa. This analysis was based on the principle that nesting sites deriving from secondary introductions should contain a subset of the alleles present in the nesting site of origin.

\section{Association between levels of aggression, chemical and genetic distances}

To test for an association between the level of aggression, chemical distance (Euclidian distance based on CHCs) and genetic distance (pairwise $F_{\mathrm{ST}}$ ) between nesting sites, we performed Mantel tests by using the non-parametric Spearman test with XLSTAT 2011. We determined statistical significance by performing 10000 random permutations. Mantel tests were performed both with and without the Catalonian supercolony.

\section{Results}

\section{Behavioural tests}

The tests of aggression between workers from all nesting sites confirmed the existence of three supercolonies in southern Europe, the Catalonian supercolony and the Main supercolony already described by Giraud et al. (2002), as well as the Corsican supercolony identified by Blight et al. (2010) (Table 1). This Corsican supercolony was composed of eight nesting sites in Corsica (AJA, BIG, CAM, LIA, OL, PVE, SGI and TIZ), three in continental France (ANT, FRE and THE) and one in Spain (SFG). The Main supercolony contained two nesting sites in Corsica (CAL and CAN) and three in continental France (CEY, DAN and EMB) (Fig. 1).

No aggression was recorded between workers from the same nesting site (Main supercolony: mean $\pm \mathrm{SE}=1 \pm 0, n=4$; Corsican supercolony: mean $\pm \mathrm{SE}$ $=1 \pm 0, n=11$; Catalonian supercolony: 1, $n=1$ ) and from sites of the same supercolony (Main supercolony: $1.05 \pm 0.05, n=10$; Corsican supercolony: $1.05 \pm 0.03$, $n=66$ ). The level of aggression between sites of the Corsican and Main supercolonies varied from moderate to high (mean $\pm \mathrm{SE}=3.80 \pm 0.05, n=60$ ) and was significantly higher than the level of aggression within the Main and Corsican supercolonies (both $P<0.0001$, Mann-Whitney $U$ tests). By contrast, aggression was invariably high when workers of these two supercolonies were paired with workers of the Catalonian supercolony (Corsican vs. Catalonian supercolonies: $5 \pm 0$, $n=12$; Main vs. Catalonian supercolonies: $5 \pm 0, n=5$ ) In both cases, the level of aggression was higher than between the Main and Corsican supercolonies (both $P<0.0001$, Mann-Whitney $U$ tests). Three video 
Table 1 Indices of aggression (left part) and percentages of mortality after $24 \mathrm{~h}$ (right part) for each nest pair across replicates and within-nest confrontations

\begin{tabular}{|c|c|c|c|c|c|c|c|c|c|c|c|c|c|c|c|c|c|c|}
\hline Nesting-sites & OL & AJA & LIA & BIG & PVE & SGI & TIZ & CAM & FRE & ANT & THE & SFG & CAL & CAN & CEY & EMB & DAN & $\mathrm{CDE}$ \\
\hline OL & $1-0$ & 3.7 & 4.7 & 4.2 & 3.2 & 1.8 & 5.9 & 2.8 & 4.7 & 6.2 & 3.8 & 4.4 & 19.5 & 15.9 & 12.9 & 31.7 & 49 & 80.1 \\
\hline AJA & 1 & $1-1.5$ & 8.8 & 3.1 & 1.7 & 4 & 5.2 & 5 & 2.8 & 6.4 & 3.8 & 4.8 & 3.6 & 24.3 & 21 & 16.3 & 17 & 75.8 \\
\hline LIA & 1.33 & 1 & $1-6.1$ & 5 & 4.6 & 3.8 & 4.6 & 1.8 & 2.8 & 2.3 & 2.9 & 5.6 & 9.9 & 3.7 & 11.2 & 9.2 & 11.9 & 70 \\
\hline BIG & 1 & 2 & 1 & - & 5.7 & 6.4 & 3.1 & 1.5 & 3.6 & 2.5 & 4.1 & 3.9 & 12.3 & 2.3 & 8.8 & 26.5 & 17.7 & 64.2 \\
\hline PVE & 1 & 1 & 1.33 & 1.33 & $1-5.1$ & 4.5 & 1.5 & 1.2 & 4.8 & 8.8 & 3.9 & 3.1 & 4.7 & 5.1 & 5.6 & 16.8 & 24.1 & 57.3 \\
\hline SGI & 1 & 1 & 1 & 1 & 1 & $1-2.4$ & 3.8 & 3.7 & 4.5 & 5.5 & 3.8 & 5.2 & 4.7 & 11.7 & 4.6 & 36.6 & 32.7 & 65.3 \\
\hline TIZ & 1 & 1.33 & 1 & 1 & 1 & 1 & 1-1.1 & 3.4 & 2.6 & 6.4 & 3 & 1.1 & 4.6 & 10 & 20.5 & 22.4 & 23 & 70.8 \\
\hline CAM & 1 & 1 & 1 & 1 & 1 & 1 & 1 & $1-0.8$ & 2.5 & 9 & 1.3 & 2.2 & 16 & 17.3 & 10.1 & 19 & 18.9 & 68.6 \\
\hline FRE & 1 & 1 & 1 & 1 & 1 & 1 & 1 & 1 & $1-0.5$ & 6.3 & 2.1 & 4.4 & 5.3 & 6.7 & 3.6 & 7.6 & 4.8 & 72.4 \\
\hline ANT & 1.67 & 1 & 1 & 1 & 1 & 1 & 1 & 1 & 1 & $1-1.5$ & 3.7 & 10.8 & 1.6 & 8.9 & 8.3 & 18.7 & 29.2 & 69.5 \\
\hline THE & 1 & 1 & 1 & 1 & 1 & 1 & 1 & 1 & 1 & 1.33 & $1-0.5$ & 3.6 & 3.6 & 5.2 & 4.3 & 17.9 & 18.6 & 72 \\
\hline SFG & 2 & 1.33 & 2 & 1 & 1 & 1.33 & 1.33 & 1 & 1 & 3.67 & 1 & $1-0.5$ & 3.9 & 4.9 & 6.6 & 13.9 & 12.7 & 74 \\
\hline CAL & 4 & 4 & 3 & 4 & 3 & 4 & 3.5 & 3.5 & 3 & 3 & 3 & 4 & - & 3 & 7.2 & 2 & 2 & 61 \\
\hline CAN & 4.67 & 4.33 & 3.33 & 3 & 3.33 & 3.67 & 3.67 & 4 & 3 & 4.5 & 4 & 4 & 1 & $1-2.5$ & 5 & 3.5 & 5 & 68.1 \\
\hline CEY & 4.33 & 4.33 & 4 & 3.67 & 3.67 & 3.67 & 4 & 4 & 3.67 & 3.67 & 3.67 & 4 & 1.5 & 1 & $1-1.5$ & 1.6 & 1.9 & 72.1 \\
\hline EMB & 4.67 & 4 & 4 & 4.33 & 4 & 4 & 4 & 4 & 4 & 4.33 & 4 & 3.67 & 1 & 1 & 1 & $1-3.6$ & 3.2 & 74.8 \\
\hline DAN & 4.67 & 4 & 4 & 4.33 & 3.67 & 4 & 4 & 4 & 4 & 4 & 3.33 & 4 & 1 & 1 & 1 & 1 & $1-2.7$ & 71.3 \\
\hline CDE & 5 & 5 & 5 & 5 & 5 & 5 & 5 & 5 & 5 & 5 & 5 & 5 & 5 & 5 & 5 & 5 & 5 & $1-4.1$ \\
\hline
\end{tabular}

AJA, Ajaccio; ANT, Anthéor; BIG, Biguglia; CAL, Calvi; CAM, Campomoro; CAN, Cannella; CDE, Caldès d'Estrac; CEY, Ceyreste; DAN, Danio; EMB, Les Embiez; FRE, Fréjus; LIA, Liamone; OL, Olmeto; PVE, Porto-Vecchio; SFG, Sant Feliù de Guixols; SGI, Santa Giulia; THE, Théoule; TIZ, Tizzano.

Values in bold indicate pairs of nesting-sites assigned to the Main and Corsican supercolonies.

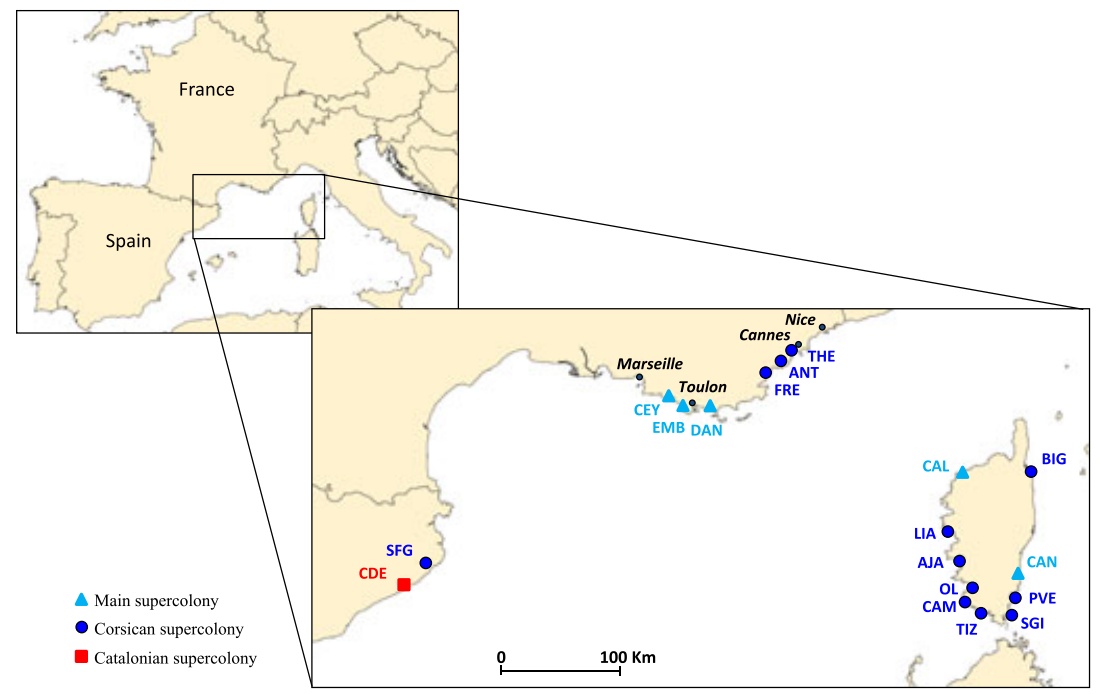

Fig. 1 Geographical location of the 18 studied nesting sites of Linepithema humile in southern Europe, and their affiliation to the three supercolonies based on the behavioural data; the Catalonian supercolony (square), the Corsican supercolony (dots) and the Main supercolony (triangles).

sequences of confrontations between the Main (EMB) and Corsican (OL) supercolonies, between the Corsican (BIG) and Catalonian supercolonies, and within the Main supercolony (CEY) are available as accessible data on Dryad.

Overall, there was considerable variability among workers in the level of aggression in encounters between sites of the Corsican and Main supercolonies with some workers eliciting fights, whereas others moved freely from one nest to the other. In complete contrast, all workers were highly aggressive when workers of either the Main or the Corsican supercolonies were paired with workers of the Catalonian supercolony. These differences in the level of aggression resulted in differences in mortality rate (Table 1$)$. The percentage of dead workers was $2.2 \pm 0.4 \%(n=16)$ for confrontations within nesting sites, $4.1 \pm 0.2 \% \quad(n=66)$ for confrontations within the Corsican supercolony, 
$3.4 \pm 0.8 \%(n=10)$ for confrontations within the Main supercolony, $13.7 \pm 1.3 \% \quad(n=60)$ for confrontations between the Main and Corsican supercolonies, $70 \pm 1.7 \%(n=12)$ for confrontations between the Corsican and Catalonian supercolonies and $69.5 \pm 2.4 \%$ $(n=5)$ for confrontations between the Main and Catalonian supercolonies. The mortality rates were significantly higher in confrontations between the MainCatalonian and Corsican-Catalonian supercolonies than those between Main-Corsican supercolonies (both $P<0.0001$, Mann-Whitney $U$ tests).

\section{Cuticular hydrocarbon analysis}

Based on the pooled samples of workers from the three nesting sites representing the three supercolonies, we identified $135 \mathrm{CHCs}$ ranging in chain length from 25 to 51 carbon atoms. Cuticular profiles of Argentine ant workers were dominated by methyl-branched alkanes (mono-, di- and trimethyl), although some straightchain n-alkanes and n-alkenes were present (Table S1, Supporting information). The profile of workers from the Catalonian supercolony was more diverse and wide ranging than the profiles of workers from the two other supercolonies. We identified 97 hydrocarbons ranging from 25 to 51 carbon chain lengths in the profile of workers from the Catalonian supercolony (Fig. 2A), 49 hydrocarbons ranging from 25 to 40 carbon atoms in the profile of workers from the Main supercolony (Fig. 2B) and 55 hydrocarbons ranging from 25 to 41 carbon atoms in the profile of workers from the Corsican supercolony (Fig. 2C). Only $16 \mathrm{CHCs}$ were common to the three supercolonies (Table S1, Supporting information). The number of hydrocarbons in common between workers of different supercolonies was 18 for the Catalonian and Main supercolonies, 20 for the Catalonian and Corsican supercolonies, and 44 for the Main and Corsican supercolonies. However, in cases in which several compounds eluted as a single peak, there were occasions where one of the components comprising the peak was common to two or more of the supercolonies but not the other coeluting compounds.

The PCA, based on the proportions of the 51 major CHCs of the 10 individuals from each of the 18 nesting sites, separated the nesting site from the Catalonian supercolony from the others on PC1 that accounted for $39.99 \%$ of the total variance (Fig. 3). For the remaining nesting sites, discrimination was less pronounced and, projected on PC2, accounted for $12.50 \%$ of the total variance. The $k$-means analysis identified three chemical groups that matched perfectly with the three supercolonies identified by the behavioural tests (1000 permutations were used to assess an optimum number of three groups). All individuals from a given location were assigned to the same group, except for one worker from CAL and one from TIZ, which were assigned to other groups.

\section{Genetic analyses}

The three supercolonies could not be clearly distinguished on the basis of the genetic data. The Bayesian analysis performed with STRUCTURE clearly distinguished the CDE nesting site (Catalonian supercolony) from the others. The most probable number of genetic groups was $K=2$ (see Fig. S1A, B). All the individuals sampled in CDE belonged to the first genetic group, with an average proportion of membership of 1.00 , while the other nesting sites were assigned to the second genetic group, with an average proportion of membership always higher than 0.97 (see Fig. S1). To determine whether the inclusion of CDE affected the analysis, we conducted the same analysis without the individuals from CDE. This second analysis gave very ambiguous results. According to method developed by Evanno et al. (2005), the most probable number of genetic groups was four (Fig. S1D; $K=4$ ). However, this clustering made no sense because individuals of a given nesting site were not consistently assigned to the same genetic group. Instead, they were typically assigned to each of the four genetic groups (see Fig. S2B as an example of one of the run). This probably reflects the fact that STRUCTURE does not permit to identify the true number of genetic groups when $K=1$. Indeed the analyses of $\operatorname{LnP}(\mathrm{D})$ curve (Fig. S1C) reveal that the $K$ for which the $\operatorname{LnP}(\mathrm{D})$ was highest and exhibited the lowest variation between runs was $K=1$ suggesting that the individuals of the 17 nesting sites included in the analysis form a single genetic group. When forcing $K=2$, the results were similarly very ambiguous. Individuals from each of the 17 nesting sites were assigned to both genetic groups (with proportion varying between 0.3 and 0.7 Fig. S2C).

Further analyses revealed a similar pattern with a clear genetic differentiation of the Catalonian supercolony but no clear differentiation between the Corsican and Main supercolonies. Overall, the Catalonian supercolony was highly differentiated from the two other supercolonies $\left(F_{\mathrm{ST}}\right.$ : Cat-Main $=0.47, P<0.05 ; F_{\mathrm{ST}}$ : Cat-Corsica $=0.43, P<0.05$ ) while the Main and Corsican supercolonies were only weakly differentiated ( $F_{\mathrm{ST}}$ : Corsica-Main $=0.06, P<0.05)$. Accordingly, the measures of genetic differentiation between pairs of nesting sites (Table S2, Supporting information) were invariably high between the Catalonian nesting sites and those of the two other supercolonies $\left(F_{\mathrm{ST}}\right.$ values ranging between 0.41 and 0.55 ) while differentiation between pairs of nesting sites from the Main and Corsican 

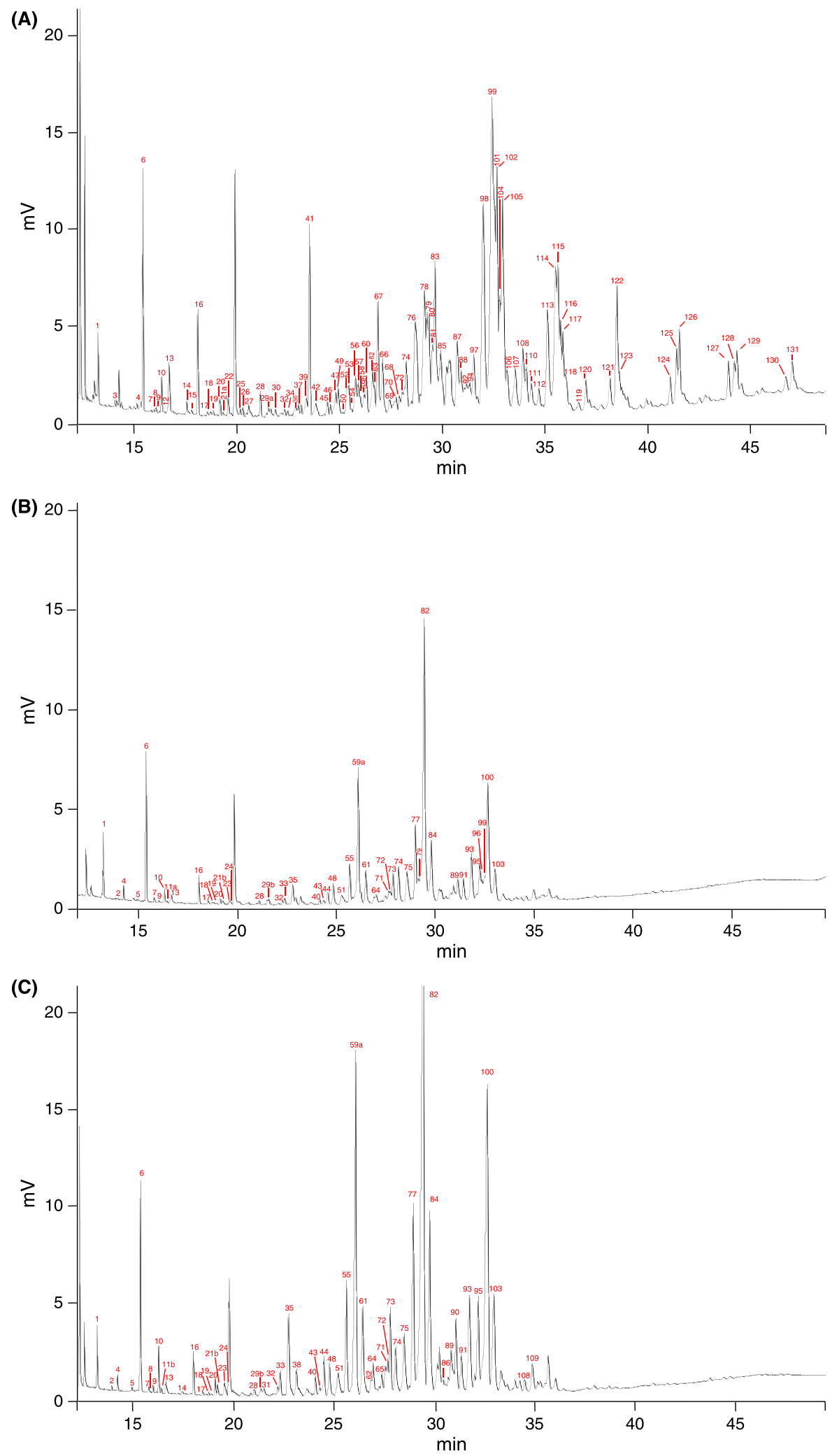

Fig. 2 Gas chromatograms of total body wash of 30 workers of Linepithema humile from (A) Caldès d'Estrac (Catalonian supercolony), (B) Ceyreste (Main European supercolony), (C) Fréjus (Corsican supercolony). Peak numbers correspond to the list of the identified cuticular hydrocarbons in Table S1. 


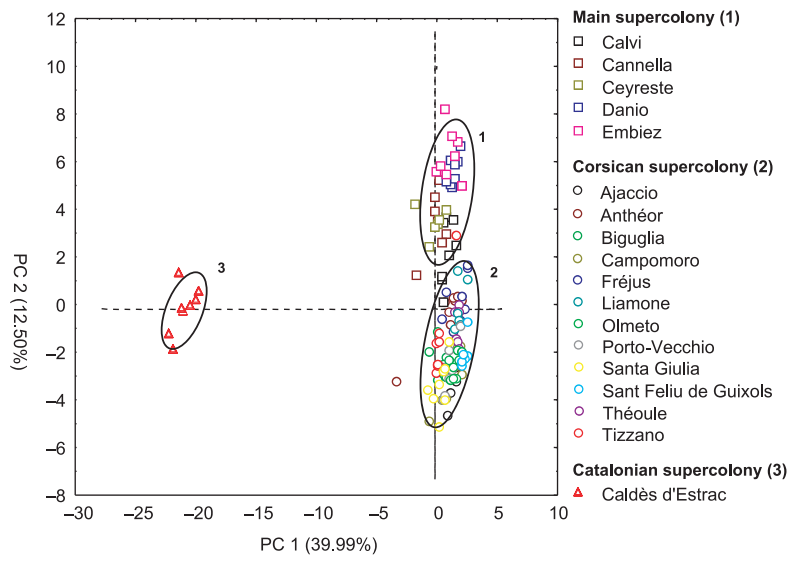

Fig. 3 Principal component analysis (PCA) of worker cuticular hydrocarbons (CHCs) from the 18 nesting sites. The PCA was based on the relative proportion of $51 \mathrm{CHCs}$. Axis 1 accounts for $39.99 \%$ of total variance and axis 2 for $12.50 \%$. Results of $\mathrm{K}$-means cluster analysis, group 1 (squares): Calvi (CAL), Cannella (CAN), Ceyreste (CEY), Danio (DAN), Les Embiez (EMB); group 2 (circles): Anthéor (ANT), Ajaccio (AJA), Biguglia (BIG), Campomoro (CAM), Fréjus (FRE), Liamone (LIA), Olmeto (OL), Porto-Vecchio (PVE), Sant Feliù de Guixols (SFG), Santa Giulia (SGI), Tizzano (TIZ), Théoule (THE); and group 3 (triangles): Caldès d'Estrac (CDE). The ellipses correspond to the $95 \%$ confidence limit of the data.

supercolonies was much smaller (between 0.04 and 0.31 ) and similar to values between nesting sites within supercolonies (between -0.01 and 0.32 ).

A hierarchical analysis revealed a similar pattern with a relatively important genetic differentiation between supercolonies when the Catalonian nesting site was considered $\left(F_{\mathrm{Sc} / \mathrm{Pop}}=0.16, P<0.001\right)$ but a much lower differentiation when it was excluded from the analysis $\left(F_{\mathrm{Sc} / \text { Pop }}=0.04, P<0.001\right)$. When only the Main and Corsican supercolonies were considered, the differentiation between nesting sites within supercolonies $\left(F_{\text {Nest } / \mathrm{Sc}}=0.10, P<0.001\right)$ was in the same order of magnitude as the differentiation between supercolonies $\left(F_{\mathrm{Sc} / \mathrm{Pop}}=0.04, P<0.001\right)$.

Finally, the PCA based on the nesting sites clearly distinguished the Catalonian nesting site from those of the other supercolonies (Fig. 4A; PC1 $=39 \%, P<0.001$ ) while those of the Main and Corsican supercolonies were not discriminated (PC2 $=16 \%, P=0.62$ ). The PCA based exclusively on the nesting sites of the Corsican and Main supercolonies also did not discriminate the two supercolonies with the first axis being non-significant (Fig. 4B; $\mathrm{PC} 1=25 \%, P=0.24 ; \mathrm{PC} 2=23 \%, P<0.01$ ).

Altogether, these data show that there is only very week differentiation between the Main and Corsican supercolonies which stands in strong contrast to the Catalonian supercolony that is strongly differentiated from both the Main and Corsican supercolonies.
To assess the relationship among the supercolonies identified in this study as well as the relationship between these supercolonies and those found worldwide, we performed a PCA based on the alleles frequencies of the 12 microsatellites. This analysis revealed high similarity of the Main and Corsican supercolonies that constituted a genetic cluster with the supercolonies from California, Australia, New Zealand, Hawaii and Japan (the S2 supercolony) (Fig. 4C). By contrast, the Catalonian supercolony was genetically very distinct from both the Main and Corsican supercolonies.

Analyses of the mitochondrial DNA were highly congruent with the microsatellite data. The analysis of the cytochrome $b$ genetic marker confirmed that the individuals from the Main and Corsican supercolonies exclusively harboured the H1 haplotype (GenBank: FJ466647.1) This is the haplotype which is also found in the other supercolonies with which the Main and Corsican supercolonies cluster (Vogel et al. 2010). By contrast, the CDE nesting site had the H9 haplotype that was previously found to characterize nesting sites of Catalonian supercolony (Vogel et al. 2010, GenBank: FJ466655.1).

A PCA of microsatellite genotypes comprising only the supercolonies genetically similar to the Main and Corsican supercolonies confirmed their high similarity (Fig. 4D). There was actually some overlap in the distribution of nesting sites of these two supercolonies along the two main axes which accounted for a high proportion of the overall variation $(\mathrm{PC} 1=38 \%, P<0.001$; PC2 $=20 \%, P<0.001)$. The genetic composition of the S2 Japanese supercolony was also very similar to that of ants from the nesting sites of the Corsican supercolony and notably to SGI and SFG. In this respect, it is important to point out a misidentification made in a previous study on the classification of the SFG nesting site. On the basis of information on the spatial distribution of the Main supercolony, Blight et al. (2010) assumed that the SFG nesting site belonged to the Main European supercolony. However, the genetic data of the study reveal that SFG and the nesting sites to which it was behaviourally and chemically clustered were closer to the S2 Japanese supercolony than to the Main supercolony described by Vogel et al. (2010). Later aggression tests with nests from Port-Leucate [known to be from the Main supercolony (Jaquiéry et al. 2005)] revealed the error (unpublished data). As a consequence, SFG actually belongs to the Corsican supercolony. Consequently, all the nesting sites identified as the Corsican supercolony by Blight et al. (2010) actually belong to the Main supercolony, and inversely all nesting sites of the Main supercolony belong to the Corsican supercolony.

To further investigate the genetic composition between the Main, Corsican and Catalonian supercolonies and test 


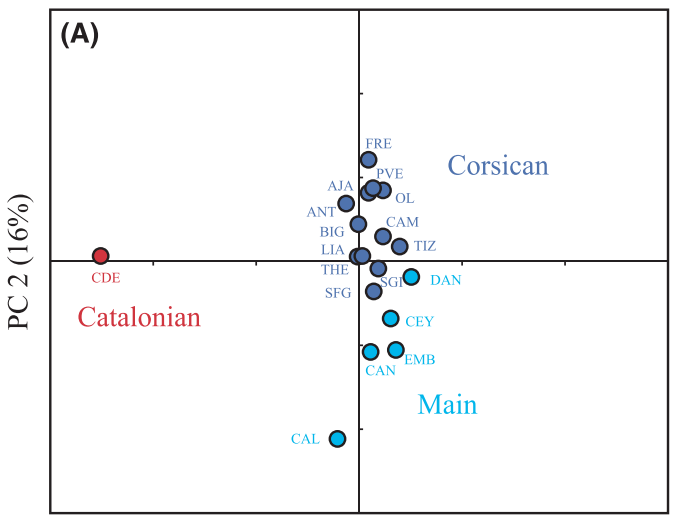

PC $1(39 \%)$

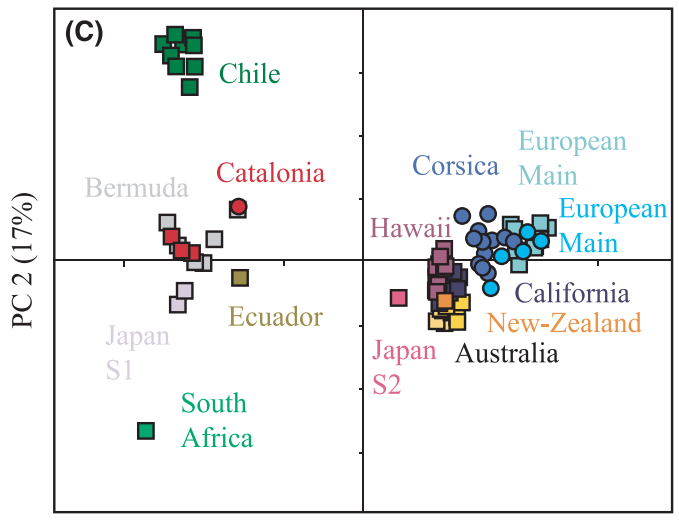

PC $1(29 \%)$

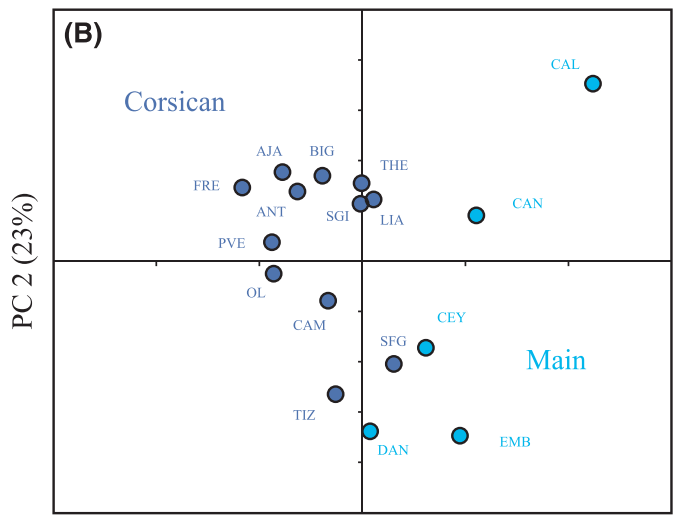

PC $1(25 \%)$

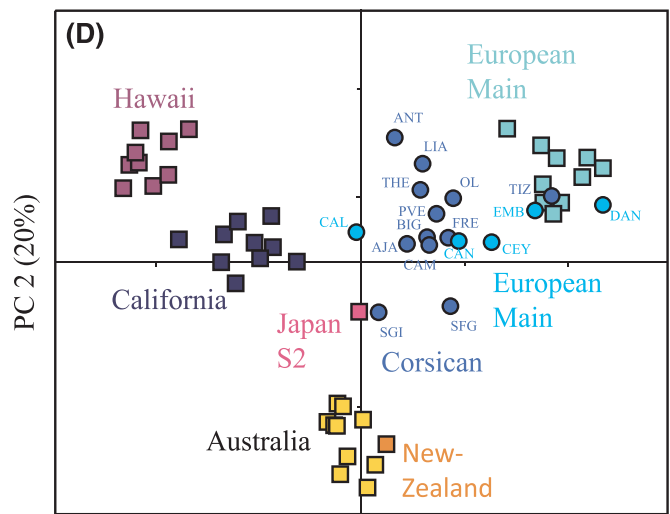

PC $1(38 \%)$

Fig. 4 Principal component analysis (PCA) based on microsatellite allele frequencies calculated on nesting sites. (A) The 18 nesting sites of the Main, the Corsican and the Catalonian supercolonies of the present study (represented by dots) were included in the analysis. (B) Analysis based exclusively on the nesting sites of the Main and Corsican supercolonies. (C) Analysis of the 18 nesting sites of the present study in relation to all the nests of the worldwide supercolonies studied in Vogel et al. (2010). (D) Analysis of the nesting sites of the Main and Corsican supercolonies in relation to the nests of the worldwide supercolonies studied in Vogel et al. (2010) that formed a cluster with those two supercolonies in the PCA presented in panel C (PC1 > 0). In panels C and D, we distinguished the nests of the European main supercolonies from the present study from those issued from the Vogel et al. (2010) study by using dots and squares, respectively. The percentage of variance explained is given for each axis in brackets.

whether one may derive from one of the two others, we measured the allelic richness and compared the proportion of alleles shared between nesting sites (allelic nestedness). Support for one supercolony originating from another supercolony would come from the derived supercolony having a high proportion of alleles being also present in the source supercolony. This analysis confirmed that the Catalonian supercolony is clearly distinct from the two other supercolonies (Fig. 5). Of the 36 alleles in common between supercolonies, 13 were present in the three supercolonies, 20 were shared between the Main and Corsican supercolonies and only three and one alleles were common to the Catalonian and Corsican supercolonies, and Catalonian and Main supercolonies, respectively. The great divergence of the Catalonian supercolony was also reflected by a lower proportion of alleles being in common between nesting sites of this supercolony and those of the two other supercolonies, compared to nesting sites of the Main and Corsican supercolonies (Table S2, Supporting information).

A comparison of the Corsican and Main supercolonies revealed a higher allelic richness for the Corsican supercolony (both when corrected and not corrected by sampling size, $P<0.05$, see Fig. 5). Accordingly, $73 \%$ of the alleles found in the Corsican supercolony were also present in the Main supercolony, while $80 \%$ of the alleles detected in the Main supercolony also occurred in the Corsican supercolony (Fig. 5). The comparison of allelic richness among nesting sites revealed a similar pattern with nesting sites of the Corsican supercolony having a higher number of alleles in $83 \%$ of the pairwise comparisons ( $P=0.01$; Fig. 5). These data, together with the high genetic similarity between the Corsican and Main European supercolonies, are compatible with the 


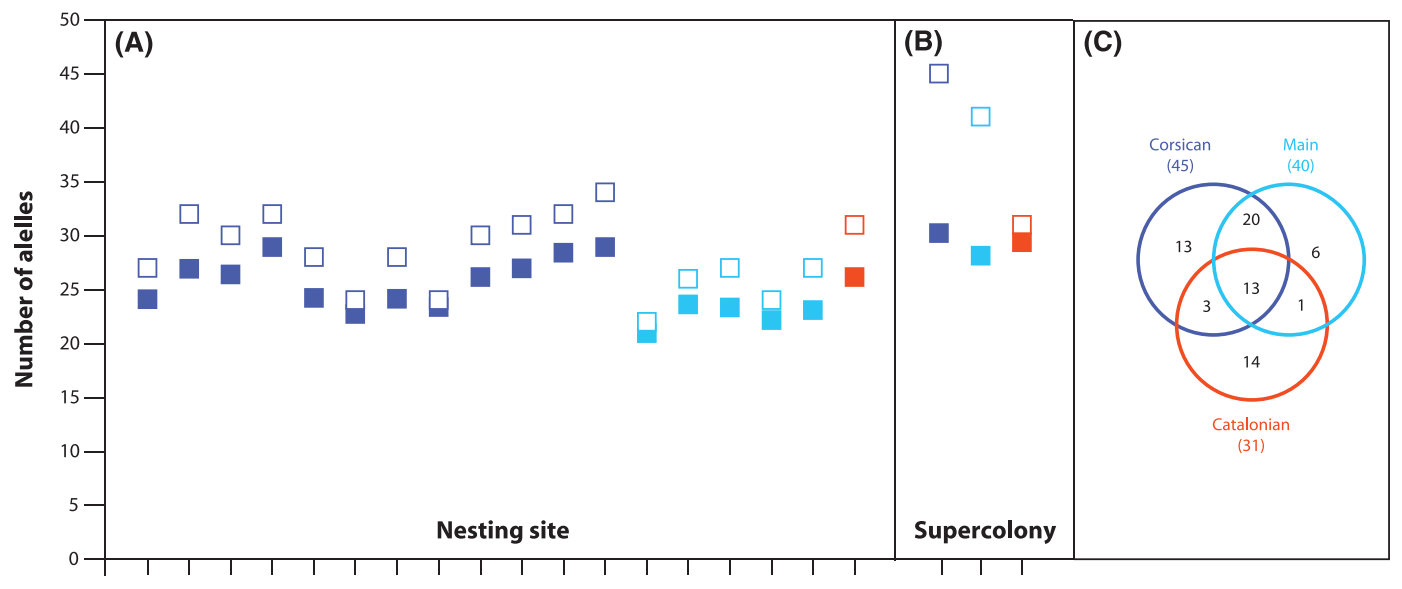

Fig. 5 Allelic richness at 12 microsatellite loci estimated for each nesting site (A) and each supercolony (B). Open squares represent the total number of alleles while the closed squares correspond to the estimated number of alleles corrected for differences in sample size. The way the alleles are distributed among the supercolonies is presented in panel (C). The total number of alleles found per supercolony is given in brackets.

Main supercolony originating from the Corsican supercolony.

\section{Association among behavioural, chemical and genetic data}

There was a high correlation between the aggression level and genetic distance $\left(r^{2}=0.41, P<0.0001\right)$, the aggression level and chemical distance, $\left(r^{2}=0.60\right.$, $P<0.0001)$ as well as the genetic and chemical distances $\left(r^{2}=0.76, P<0.0001\right)$ (Fig. 6). When the Catalonian supercolony was excluded from the analyses all correlations decreased but remained significant (aggression-genetic distance: $r^{2}=0.24, P<0.01$; aggressionchemical distance: $r^{2}=0.45, P<0.001$; genetic-chemical distances: $\left.r^{2}=0.26, P<0.001\right)$. Importantly, however, the inspection of Fig. 6 reveals that the association was nonlinear and that there was a strong effect of supercolony. The high levels of aggression, and high chemical and genetic distances were invariably found for the comparison between the Catalonian supercolony and the two other supercolonies. A second cloud of points corresponding to intermediate levels of aggression, chemical and genetic distances characterized the comparison between the Main and Corsican supercolonies. Finally, the within Main and Corsican supercolony comparisons revealed similarly low levels of aggression (1-2) and genetic and chemical distances. Overall, the differentiation between the Main and Corsican supercolonies was well marked for aggression tests and less marked for genetic and chemical distances with many Corsican-Main comparisons intermingled with the within supercolony comparisons.

\section{Discussion}

This study confirms the existence of a distinct Corsican supercolony with a distribution range including at least Corsica, south-eastern France and one location in Spain. Members of this supercolony were aggressive towards ants from the other two supercolonies studied. Aggression between workers from the Corsican and Main European supercolonies varied from moderate to high, while aggression was systematically high when workers from the Catalonian supercolony were involved. This behavioural pattern was confirmed by chemical data. Cuticular hydrocarbon proximity of members of the Corsican supercolony to members of the Main supercolony was greater than to those of the Catalonian supercolony. Surprisingly, despite the noteworthy concordance between chemical and behavioural groups, there was no clear genetic differentiation between the Main and Corsican supercolonies $\left(F_{\mathrm{ST}}=0.06\right)$. This level of genetic differentiation corresponds to the differentiation observed between nesting sites from a single supercolony. Previous studies showed that the genetic differentiation of nesting sites within a supercolony varies between 0 and 0.1 depending of the supercolonies and the scale at which the study is performed (Tsutsui \& Case 2001; Giraud et al. 2002 Jaquiéry et al. 2005; Pedersen et al. 2006; Thomas et al. 2006; Sunamura et al. 2009a; Vogel et al. 2009) while the genetic differentiation between supercolonies usually exceed 0.2 (Jaquiéry et al. 2005; Pedersen et al. 2006; Thomas et al. 2006; Sunamura et al. 2009a; Vogel et al. 2009, 2010). In line with a very weak genetic differentiation, the STRUCTURE analysis did not discriminate between the two supercolonies. This is 


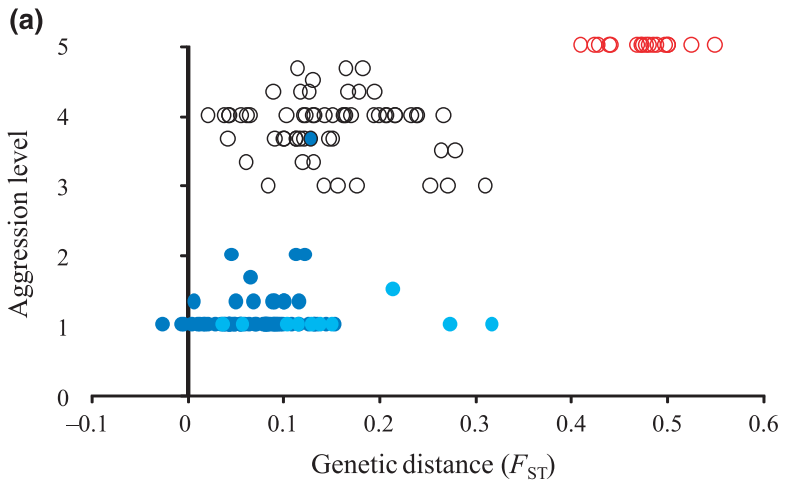

(b)

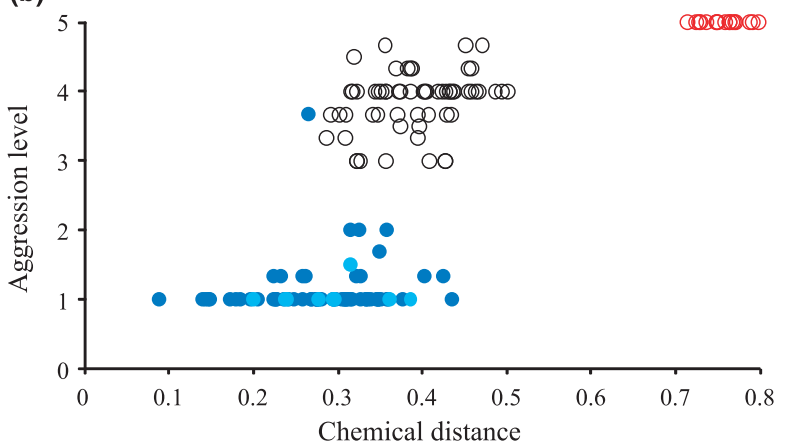

(c)

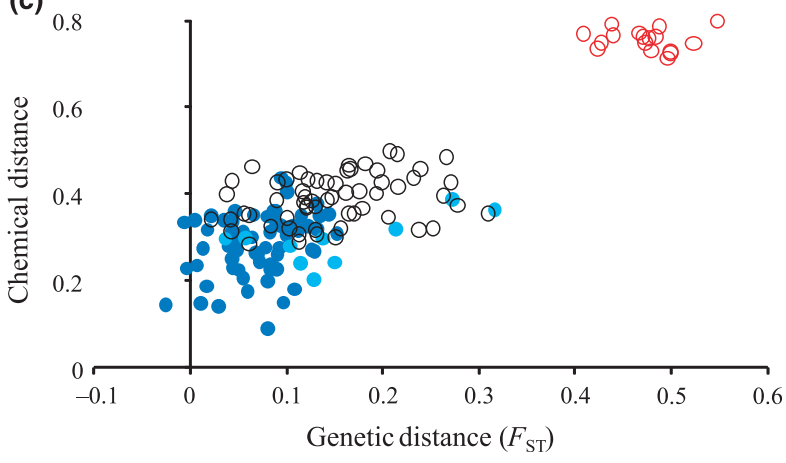

Fig. 6 The associations of pairwise genetic $\left(F_{\mathrm{ST}}\right)$, chemical and behavioural distances between the three European supercolonies of Linepithema humile. Light-blue circles represent comparisons within the Main supercolony $(n=10)$, dark-blue circles represent comparisons within the Corsican supercolony $(n=66)$, open black circles represent comparisons between the Main and Corsican supercolonies $(n=60)$ and open red circles represent comparisons between the Catalonian and both the Main and Corsican supercolonies $(n=17)$.

also supported by the central position of nesting sites from the Main and Corsican supercolonies on the PCA including peaceful-nests belonging to the worldwide supercolony and considered as genetically and chemically similar (Brandt et al. 2009; Sunamura et al. 2009b; Vogel et al. 2010; van Wilgenburg et al. 2010) (Fig. 4C, D).

The process of nestmate recognition by which the Corsican supercolony is behaviourally segregated from the Main supercolony remains unclear. There are a number of factors influencing the expression and variation of the Argentine ant chemical phenotype, including environmental and genetic factors (Liang \& Silverman 2000; Tsutsui et al. 2000; Giraud et al. 2002; Suarez et al. 2008). Environment has been hypothesized to influence nestmate recognition cues in the Argentine ant, because colonymates reared on different diets in laboratory experiments became mutually aggressive (Liang \& Silverman 2000; Silverman \& Liang 2001; Buczkowski et al. 2005). However, it seems unlikely that such differences in diet could explain the chemical differences and the aggressiveness between nesting sites of the Corsican and Main supercolonies in view of the wide dietbreadth experienced by workers of opportunistic species such as the Argentine ant (Vonshak et al. 2009) and the geographic overlap in the distribution of the two supercolonies.

Alternatively, the difference in chemical profiles and behaviour between workers of the Main and Corsican supercolonies could have a genetic basis. Consistent with a predominant role of genetic factors in nestmate recognition in Argentine ants, chemical and genetic distances were highly correlated $\left(r^{2}=0.76, \quad P<0.0001\right.$; Fig. 6B). However, when the Catalonian supercolony was excluded from the analysis, only $26 \%(P<0.001)$ of the variance in the chemical cues could be attributed to genetic distances between pairs of nesting sites. In insects, cuticular hydrocarbon synthesis is regulated by enzymes, which are themselves under the control of specific genes. Modification at these genes is sufficient to prevent the biosynthesis of a hydrocarbon (WickerThomas 2008). This has been clearly shown for Drosophila melanogaster, where a modification at the gene desat1 coding for a desaturase that is involved in sex pheromone synthesis disrupts individual sexual behaviour (Ueyama et al. 2005). Thus, there could be genetic differences at one or several loci between the Main and Corsican supercolonies that may account for odour and behavioural differences despite no clear genetic differentiation at neutral markers between supercolonies. Such a situation has been demonstrated in the fire ant Solenopsis invicta where a single genetic Mendelian factor results in strong differences in odour and behaviour between the monogyne and polygyne social forms, which show no differentiation at neutral nuclear markers (Keller \& Ross 1998; Ross \& Keller 1998; Wang et al. 2008). In line with this finding, high levels of variation in aggression remained unexplained by the overall genetic distance at the microsatellite marker loci between the Main and Corsican supercolonies $\left(r^{2}=0.24, \quad P<0.001\right)$. High aggression was present between the Main and Corsican supercolonies even when nesting sites shared relatively high proportions of 
alleles, and inversely no aggression was observed between some nesting sites sharing low proportions of alleles (Table 1 and Table S2).

Consistent with aggression being sometimes-but not always-decoupled from genetic differentiation at neutral markers, Buczkowski et al. (2004) found no clear relationship between intraspecific aggression and genetic similarity at microsatellite markers between nest pairs from California while Tsutsui et al. (2000) reported higher aggression between nests being genetically more divergent in the Argentine ant. Likewise, no relationship was detected between neutral markers and aggression across Australia (Suhr et al. 2011). Similar results were recently found in the invasive pharaoh ant (Schmidt et al. 2010) and in both the native polygynous ants Formica fusca (Helanterä et al. 2011) and Formica exsecta (Martin et al. 2011) where an increase in genetic diversity at neutral makers did not result in an increase of recognition cue diversity or changes in agonistic behaviour. In the invasive pharaoh ant, no qualitative difference was detected in chemical cues among colonies despite a very high genetic differentiation $\left(F_{\mathrm{ST}}=0.72\right)$ at neutral markers (Schmidt et al. 2010). At the opposite, the Main and Corsican supercolonies differed qualitatively at $16 \mathrm{CHCs}$ despite the weak genetic differentiation $\left(F_{\mathrm{ST}}=0.06\right)$. Most of the studies suggesting the genetic basis of recognition cues were usually based on the correlation using neutral markers. However, as correlation does not imply causation, it may offer limited insights into relationships between behaviour, chemistry and genetics and may have limited power in unravelling the pattern of nestmate discrimination. Indeed, it is possible that only a few genes could impact chemical diversity, irrespective of relatedness.

Two hypotheses have been proposed for the origin of the Corsican supercolony. Either the Corsican supercolony originated from the Main supercolony by geographic isolation (split hypothesis), or it originated from an independent introduction event from the ants' native range (Blight et al. 2010). A slightly alternative explanation is that one or both supercolonies did not originate from native populations but from introduced populations. The finding of a high genetic similarity between the Main and Corsican supercolonies both at the microsatellite loci investigated and the sharing of the same mitochondrial haplotype (H1) supports the view that they may have a common origin, either from the same supercolony (in the native range or another introduced population) or that one originates from the other. In that respect, our finding of the Corsican supercolony being genetically more diverse and having more private alleles than the Main supercolony indicates that, if one of the two supercolonies derives from the other, it is the Main supercolony deriving from the Corsican supercolony rather than the reverse as had been previ- ously proposed. It would be interesting to collect more nesting sites (in particular, for the Main supercolony), to investigate more thoroughly whether the Main supercolony really derives from the Corsican supercolony.

Historical records suggest that Argentine ants were first introduced into Madeira, which served as a source of propagules that were dispersed and invaded the Canary Islands and continental Europe (Wetterer \& Wetterer 2006). In south-eastern France, Argentine ants were first recorded in Cannes ( $10 \mathrm{~km}$ from THE) and near Toulon (between sites EMB and DAN) at the beginning of the twentieth century (Fig. 1) (Marchal 1917). Argentine ants were apparently transported from South America to Cannes with the importation of Orchids (Chopard 1921), whereas the propagule introduced near Toulon originated from the Canary Islands via the introduction of palm trees (Veyret 1961). These historical data support the view that Argentine ants in southeastern France may originate from at least two introduction events. Interestingly, there is a good match between the historical data and current distribution of the two supercolonies. Continental nesting sites assigned to the Main European supercolony are located near Toulon, whereas those assigned to the Corsican supercolony are located near Cannes.

The results obtained in this study not only enhance our understanding of the origin of Argentine ant supercolonies in Southern Europe but also shed some light on questions regarding the general origin and evolution of invasive unicolonial ant populations (Helanterä et al. 2009). It has been suggested that splitting of supercolonies can occur either through geographical isolation or behavioural processes (Drescher et al. 2010; Sunamura et al. 2011), both mechanisms contributing to reduced gene flow between supercolonies. Reduced gene flow may, in turn, lead to genetic and chemical differentiation between supercolonies. Previous work showed a complete absence of ongoing gene flow between the Main and Catalonian supercolonies (Jaquiéry et al. 2005), which could lead to a process of speciation (Helanterä et al. 2009; Drescher et al. 2010). For example, workers from the Main and the Catalonian supercolonies share only 18 of $123 \mathrm{CHCs}$ in their profiles. This is a greater difference than that reported among six Formica species in which only 14 of 41 cuticular compounds differed qualitatively between species (Martin et al. 2008). Such difference in chemical profiles is remarkable as in most ant species, qualitative differences is observed between species (Hefetz 2007). Qualitative differences in cuticular hydrocarbon profiles were previously detected between the native and introduced ranges of Wasmannia auropunctata (Errard et al. 2005) and Linepithema humile (Brandt et al. 2009), and between introduced supercolonies in both the invasive yellow crazy ant Anoplolepis 
gracilipes (Drescher et al. 2010) and L. humile (Brandt et al. 2009; Blight et al. 2010).

It has been suggested that when Argentine ant supercolonies overlap, this can lead to their fusion (Vasquez \& Silverman 2008). It is currently unknown whether gene flow still occurs between the Corsican and Main supercolonies or whether they are completely reproductively isolated as is the case of the Main and Catalonian supercolonies. Interestingly, our results show that the behavioural differentiation between nesting sites of the Main and Corsican supercolonies is greater than the genetic and chemical distance. This may suggest that the behavioural response to chemical and genetic differentiation is not linear but rather depends on some threshold differentiation at some specific genes and chemical compounds. In line with this view, the genetic differentiation between the Main and Corsican supercolonies was lower than the minimal genetic differentiation among aggressive supercolonies in the native range (Vogel et al. 2009). A nonlinear function was recently found in the ant $F$. exsecta where a small change in the Z9-alkene profile resulted in a rapid shift from nonaggressive to aggressive behaviours (Martin et al. 2011). In that respect, it would be interesting to conduct transects with the aim of determining how the genetic, chemical and behavioural clines vary across the borders of the Main and Corsican supercolonies and see how these variables vary over time.

This study provides new insights into the complex nestmate recognition system of invasive ants which is a main factor driving their evolution. To the best of our knowledge, it constitutes the first report of aggression between supercolonies that are not clearly discriminated by genetics in introduced populations of the Argentine ant. Contrary to previous opinion, we demonstrate that genetically similar nests at microsatellite markers do not necessarily belong to the same supercolony, highlighting the importance of conducting more qualitative and quantitative studies on levels of aggression between supercolonies and combines such data with genetic and chemical data.

\section{Acknowledgements}

Comments made by four anonymous reviewers have greatly improved this manuscript. This work was supported by a grant from the Office de l'Environnement de la Corse, the Direction Régionale de l'Environnement de Corse and the Provence-Alpes-Côtes d'Azur region, and the Swiss NSF.

\section{References}

Blight O, Renucci M, Tirard A, Orgeas J, Provost E (2010) A new colony structure of the invasive Argentine ant
(Linepithema humile) in Southern Europe. Biological Invasions, 12, 1491-1497.

Brandt M, van Wilgenburg E, Tsutsui ND (2009) Global-scale analyses of chemical ecology and population genetics in the invasive Argentine ant. Molecular Ecology, 18, 997-1005.

Buczkowski G, Vargo EL, Silverman J (2004) The diminutive supercolony: the Argentine ants of the southeastern United States. Molecular Ecology, 13, 2235-2242.

Buczkowski G, Suib S, Kumar R, Silverman J (2005) Shared exogenous cues diminish intercolony aggression in the Argentine ant (Linepithema humile). Journal of Chemical Ecology, 31, 829-843.

Chopard L (1921) La fourmi d'Argentine Iridomyrmex humilis var. Arrogans Santschi dans le midi de la France. Annales des Epiphyties, 7, 237-265.

Drescher J, Blüthgen N, Schmitt T, Bühler J, Feldhaar H (2010) Societies drifting apart? Behavioural, genetic and chemical differentiation between supercolonies in the yellow crazy ant Anoplolepis gracilipes. PLoS ONE, 5, 1-8.

Errard C, Delabie J, Jourdan H, Hefetz A (2005) Intercontinental chemical variation in the invasive ant Wasmannia auropunctata (Roger) (Hymenoptera Formicidae): a key to the invasive success of a tramp species. Naturwissenschaften, 92, 319-323.

Evanno G, Regnaut S, Goudet J (2005) Detecting the number of clusters of individuals using the software STRUCTURE: a simulation study. Molecular Ecology, 14, 2611-2620.

Giraud T, Pedersen JS, Keller L (2002) Evolution of supercolonies: the Argentine ants of Southern Europe. Proceedings of the National Academy of Sciences, 99, 60756079.

Goudet J (1995) FSTAT (Version 1.2): a computer program to calculate F-statistics. Journal of Heredity, 86, 485-486.

Goudet J (2000) PCAGEN, a program to perform Principal Component Analysis (PCA) on gene frequency data.

Goudet J (2005) HIERFSTAT, a package for R to compute and test hierarchical F-statistics. Molecular Ecology Notes, 5, 184 186.

Hartigan JA, Wong MA (1979) A k-means clustering algorithm. Algorithm AS136, Application of Statistics 28, pp. 100-108.

Hefetz A (2007) The evolution of hydrocarbon pheromone parsimony in ants (Hymenoptera: Formicidae)-interplay of colony odor uniformity and odor idiosyncrasy. A review. Myrmecological News, 10, 59-68.

Helanterä H, Strassmann JE, Carrillo J, Queller DC (2009) Unicolonial ants: where do they come from, what are they, and where are they going? Trends in Ecology and Evolution, 24, 341-349.

Helanterä H, Lee RY, Drijfhout FP, Martin SJ (2011) Genetic diversity, colony chemical phenotype, and nest mate recognition in the at Formica fusca. Behavioral Ecology, 22, 710-716.

Hölldobler B, Wilson EO (1990) The Ants. The Belknap Press of the Harvard University Press, Cambridge, Massachusetts, $742 \mathrm{p}$.

Holway DA (1999) Competitive mechanisms underlying the displacement of native ants by the invasive Argentine ant. Ecology, 80, 238-251.

Holway DA, Case TJ (2001) Effects of colony-level variation on competitive ability in the invasive Argentine ant. Animal Behaviour, 61, 1181-1192. 
Holway DA, Suarez AV, Case TJ (1998) Loss of intraspecific Aggression in the success of a widespread invasive social insect. Science, 282, 949-952.

Holway DA, Lach L, Suarez AV, Tsutsui ND, Case TJ (2002) The causes and consequences of ant invasions. Annual Review of Ecology and Systematics, 33, 181-233.

Human KG, Gordon DM (1996) Exploitation and interference competition between the invasive Argentine ant, Linepithema humile, and native ant species. Oecologia, 105, 405-412.

Jaquiéry J, Vogel V, Keller L (2005) Multilevel genetic analyses of two European supercolonies of the Argentine ant, Linepithema humile. Molecular Ecology, 14, 589-598.

Keller L, Ross KG (1998) Selfish genes: a green beard in the red fire ant. Nature, 394, 573-575.

Krieger MJB, Keller L (1999) Low polymorphism at 19 microsatellite loci in a French population of Argentine ants (Linepithema humile). Molecular Ecology, 8, 1078-1080.

Lahav S, Soroker V, Hefetz A (1999) Direct behavioral evidence for hydrocarbons as ant recognition discriminators. Naturwissenschaften, 86, 246-249.

Le Breton J, Delabie JHC, Chazeau J, Dejean A, Jourdan H (2004) Experimental evidence of large-scale unicoloniality in the tramp ant Wasmannia auropunctata (Roger). Journal of Insect Behavior, 17, 263-271.

Liang D, Silverman J (2000) "You are what you eat": diet modifies cuticular hydrocarbons and nestmate recognition in the Argentine ant, Linepithema humile. Naturwissenschaften, 87, 412-416.

Marchal P (1917) La fourmi d'Argentine (Iridomyrmex humilis Mayr). Bulletin de la Société d'Etude et de Vulgarisation de la Zoologie Agricole, 16, 10.

Martin SJ, Helantëra H, Drijfhout FP (2008) Evolution of species-specific cuticular hydrocarbon patterns in Formica ants. Biological Journal of the Linnean Society, 95, 131-140.

Martin SJ, Vitikainen E, Drijfhout FP, Jackson D (2011) Conspecific ant aggression is correlated with chemical distance, but not with genetic or spatial distance. Behavior Genetics, 42, 323-331.

de Meeus T, Goudet J (2007) A step-by-step tutorial to use HierFstat to analyse populations hierarchically structured at multiple levels. Infection, Genetics and Evolution, 7, 731735.

Pedersen JS, Krieger MJB, Vogel V, Giraud T, Keller L (2006) Native supercolonies of unrelated individuals in the invasive Argentine ant. Evolution, 60, 782-791.

Petit RJ, El Mousadik A, Pons O (1998) Identifying populations for conservation on the basis of genetic markers. Conservation Biology, 12, 844-855.

Pritchard JK, Matthew S, Peter D (2000) Inference of population structure using multilocus genotype data. Genetics, 155, 945-959.

Provost E, Blight O, Tirard A, Renucci M (2008) Hydrocarbons and insects' social physiology. In: Insect Physiology: New Research (ed. Maes RP), pp. 19-72. Novascience Publishers, New York, NY, USA.

Ross KG, Keller L (1998) Genetic control of social organization in an ant. Proceedings of the National Academy of Sciences, 95, 14232-14237.

Schmidt AM, d'Ettore P, Pedersen JS (2010) Low levels of nestmate discrimination despite high genetic differentiation in the invasive pharaoh ant. Frontiers in Zoology, 7, 20.
Silverman J, Liang D (2001) Colony disassociation following diet partitioning in a unicolonial ant. Naturwissenschaften, 88, 73-77.

Smith BH, Breed MD (1995) The chemical basis for nestmate recognition and mate discrimination in social insects. In: Chemical Ecology of Insects II (eds Carde RT and Bell WJ), pp. 287-317. Chapman and Hall, New York.

Suarez AV, Holway DA, Case TJ (2001) Patterns of spread in biological invasions dominated by long-distance jump dispersal: insights from Argentine ants. Proceedings of the National Academy of Sciences, 98, 1095-1100.

Suarez AV, Holway DA, Tsutsui ND (2008) Genetics and behavior of a colonizing species: the invasive Argentine ant. The American Naturalist, 172, 72-84.

Suhr EL, McKechnie SW, O'Dowd DJ (2009) Genetic and behavioural evidence for a city-wide supercolony of the invasive Argentine ant Linepithema humile (Mayr) (Hymenoptera: Formicidae) in southeastern Australia. Australian Journal of Entomology, 48, 79-83.

Suhr EL, O'Dowd DJ, McKechnie SW, Mackay DA (2011) Genetic structure, behaviour and invasion history of the Argentine ant supercolony in Australia. Evolutionary Applications, 4, 471-484.

Sunamura E, Hatsumi S, Karino S et al. (2009a) Four mutually incompatible Argentine ant supercolonies in Japan: inferring invasion history of introduced Argentine ants from their social structure. Biological Invasions, 11, 2329-2339.

Sunamura E, Espadaler X, Sakamoto H, Suzuki S, Terayama M, Tatsuki S (2009b) Intercontinental union of Argentine ants: behavioral relationships among introduced populations in Europe, North America, and Asia. Insect Sociaux, 56, 143-147.

Sunamura E, Hoshizaki S, Sakamoto H et al. (2011) Workers select mates for queens: a possible mechanism of gene flow restriction between supercolonies of the invasive Argentine ant. Naturwissenschaften, 98, 361-368.

Thomas ML, Payne-Makrisâ CM, Suarez AV, Tsutsui ND, Holway DA (2006) When supercolonies collide: territorial aggression in an invasive and unicolonial social insect. Molecular Ecology, 15, 4303-4315.

Thomas ML, Becker K, Abbott K, Feldhaar H (2010) Supercolony mosaics: two different invasions by the yellow crazy ant, Anoplolepis gracilipes, on Christmas Island, Indian Ocean. Biological Invasions, 12, 677-687.

Tsutsui ND, Case TJ (2001) Population genetics and colony structure of the Argentine ant (Linepithema humile) in its native and introduced range. Evolution, 55, 976-985.

Tsutsui ND, Suarez AV, Holway DA, Case TJ (2000) Reduced genetic variation and the success of an invasive species. Proceedings of the National Academy of Sciences, 97, 5948-5953.

Ueyama M, Chertemps T, Labeur C, Wicker-Thomas C (2005) Mutations in the desat1 gene reduces the production of courtship stimulatory pheromones through a marked effect on fatty acids in Drosophila melanogaster. Insect Biochem. Molecular Biology, 35, 911-920.

Vasquez GM, Silverman J (2008) Intraspecific aggression and colony fusion in the Argentine ant. Animal Behaviour, 75, 583-593.

Veyret M (1961) La fourmi d'Argentine dans la région toulonnaise. Bulletin de la Société des Sciences Naturelles et d'Archéologie de Toulon et du Var, janvier-février, 132. 
Vogel V, Pedersen JS, D'Ettorre P, Lehmann L, Keller L (2009) Dynamics and genetic structure of Argentine ant supercolonies in their native range. Evolution, 63, 1377-1671.

Vogel V, Pedersen JS, Giraud T, Krieger MJB, Keller L (2010) The worldwide expansion of the Argentine ant. Diversity and Distribution, 16, 170-186.

Vonshak M, Dayan T, Foucaud J, Estoup A, Hefetz A (2009) The interplay between genetic and environmental effects on colony insularity in the clonal invasive little fire ant Wasmannia auropunctata. Behavioural Ecology and Sociobiology, 63, 1667-1677.

Wang J, Ross KG, Keller L (2008) Genome-wide expression patterns and the genetic architecture of a fundamental social trait. PLoS Genetics, 4, e1000127. doi:10.1371/ journal.pgen.1000127.

Wetterer JK, Wetterer AL (2006) A disjunct Argentine ant metacolony in Macaronesia and Southwestern Europe. Biological Invasions, 8, 1123-1129.

Wicker-Thomas C (2008) Biosynthèse et évolution des phéromones chez les insectes. Biofutur, 286, 28-31.

van Wilgenburg E, Torres C, Tsutsui ND (2010) The global expansion of a single ant supercolony. Evolutionary Applications, 3, 136-143.

O.B.'s main research focus is the ecology of invasive ants. This work is part of his PhD project on the social structure, invasion dynamics and ecological impacts of Argentine ants in Corsica, and of L.B.'s Master thesis project. The main research interest of V.V. is the population and evolutionary genetics of many organisms (e.g. ants and bacteria). A.H., M.R., and E.P. (OB $\mathrm{PhD}$ co-supervisor) are engaged in research on several aspects in the chemical ecology of social insects. The main research interest of J.O. (OB PhD co-supervisor) is the population and community structure of many insects. L.K. works on various aspects of evolutionary ecology and social behavior in ants.

\section{Data accessibility}

DNA sequences: Linepithema humile haplotype H1 cytochrome b (Cytb) gene, partial cds; mitochondrial, GenBank: FJ466647.1.
Linepithema humile haplotype H9 cytochrome b (Cytb) gene, partial cds; mitochondrial. GenBank: FJ466655.1.

Microsatellite genotypes for each individual, DNA sequence alignment, cuticular hydrocarbons and results of behavioural tests : DRYAD entry doi:10.5061/dryad.1kc982n5.

Video sequences: Examples of confrontations between the Main (CAN) and Corsican (OL) supercolonies, between the Corsican (BIG) and Catalonian supercolonies, and within the Main supercolony (CEY). DRYAD entry doi:10.5061/dryad.1kc982n5.

\section{Supporting information}

Additional supporting information may be found in the online version of this article.

Table S1 List of the identified cuticular hydrocarbons of workers from Caldès d'Estrac (Catalonian supercolony), Ceyreste (Main supercolony) and Fréjus (Corsican supercolony).

Table S2 Proportions of shared alleles between the three European supercolonies of Linepithema humile (left part) and $F_{\mathrm{ST}}$ values (right part).

Fig. S1 Results of the analysis performed with the software STRUCTURE including all the nesting sites (A and B), and the analysis where the Catalonian nesting sites (CDE) was excluded (C and D).

Fig. S2 Assignment of individuals into genetic groups resulting from the analyses performed with the software STRUCTURE when individuals of all nesting sites were included and when $K=2$ (panel A), when individuals of all nesting sites were included except those of the Catalonian nesting site (CDE) and when $K=4$ (panel B) and when individuals of all nesting sites were included except those of the Catalonian nesting site (CDE) and when $K=4$ (panel C).

Please note: Wiley-Blackwell are not responsible for the content or functionality of any supporting information supplied by the authors. Any queries (other than missing material) should be directed to the corresponding author for the article. 